\title{
KAJIAN SEMIOTIK LUKISAN KAWAN-KAWAN REVOLUSI KARYA S. SUDJOJONO
}

\author{
Muhammad Ghifari ${ }^{1 *}$, Susandro $^{2 *}$, Hatmi Negria $\operatorname{Taruan}^{3 *}$ \\ Program Studi Desain Komunikasi Visual ${ }^{1^{*}}$, Program Studi Seni Teater ${ }^{*}$, Program Studi Seni Rupa dan Desain ${ }^{3 *}$ \\ Jurusan Seni Rupa dan Desain ${ }^{1}$ dan 3* , Jurusan Seni Pertunjukan ${ }^{2 *}$ \\ Institut Seni Budaya Indonesia (ISBI) Aceh \\ Jl. Transmigrasi, Gampong Bukit Meusara, Kec. Kota Jantho, Kab. Aceh Besar, 23911. \\ Aceh. Indonesia \\ Email: muhammadghifari@isbiaceh.ac.id
}

\begin{abstract}
Abstrak
Lukisan yang diberi judul "Kawan-kawan Revolusi” karya S.Sudjojono menggambarkan beberapa orang yang dapat diasumsikan berjasa dalam memperjuangkan kemerdekaan Indonesia. Meski sebagian besar karakter tidak secara jelas menggambarkan suatu tokoh, namun karakter dalam gambar tersebut sekiranya cukup jelas menggambarkan sosok pejuang dari kaum laki-laki. Oleh karena itu, gambar tersebut memancing sejumlah pertanyaan yang cukup menggelitik. Di samping itu, dapat secara jelas dilihat sebagian besar karakter menoleh ke arah kanan, tidak satupun ke keiri. Sekilas hal tersebut mungkin dipandang biasa, namun jika ditinjau dari latar belakang hidup Sudjojono, terutama ideologinya, gestur karakter pada lukisannya itu menyiratkan suatu makna atau bahkan beragam makna. Pendek kata, bentuk dan makna nan ambigu menjadi sasaran dalam penelitian ini lebih jauh. Penelitian dilakukan dengan metode studi pustaka dengan berlandaskan pada teori semiotika Ferdinand de Saussure. Pembacaan dengan menggunakan kerangka semiotik dapat dilakukan tentu menghubungkan gambar dengan semangat zaman pada masa Sudjojono membuat karya tersebut.
\end{abstract}

Kata Kunci: kawan-kawan revolusi, bentuk, makna.

\begin{abstract}
The painting entitled "Friends of the Revolution" by S. Sudjojono assesses some people who can be assumed to be instrumental in fighting for Indonesian independence. Although most of the characters do not clearly depict characters, but the characters in the picture are quite clearly depicting male warriors. Therefore, the picture supports a number of questions that are quite intriguing. In addition, it can be displayed that most characters turn to the right, not according to the left. This overview may look ordinary, but when viewed from the background of Sudjojono's life, especially his ideology, the characters in his paintings imply a meaning or even a variety of meanings. Short words, forms, and meanings, ambiguous, are subject to further research. The study was conducted using the literature study method with Ferdinand de Saussure's semiotic theory based. Reading using semiotics can, of course, connect the images with the spirit of the times when Sudjojono made the work.
\end{abstract}

Keywords: comrades of the revolution, form, meaning.

\section{PENDAHULUAN}

"Seni adalah jiwa ketok" (jiwa yang tampak). Kalimat ini adalah prinsip S. Sudjojono (1914-1986) dalam mendalami seni rupa terutama ditekankan pada muridmuridnya dalam membesarkan perkembangan seni rupa Indonesia di bawah organisasi yang dinamakan dengan PERSAGI (Persatuan Ahli Gambar Indonesia), didirikan pada tahun 1937 (Soedarso: 2000). Sudjojono disebut sebagai bapak seni rupa Indonesia atas sepak terjangnya dalam membina dan mengembangkan seni lukis di mana Indonesia dalam masa krisis sosial, politik, dan ekonomi.

Salah satu lukisan yang menggambarkan suatu kondisi masyarakat di zaman S.Sudjojono berjudul 'Kawankawan Revolusi'. Selintas lukisan ini menggambarkan tokoh-tokoh yang terkesan heroik dalam mengembangkan semangat perjuangan di segenap penjuru Bangsa Indonesia.

Namun saat ini, arti kata dari "kawan-kawan" dan "revolusi" mesti harus dipertanyakan atau ditafsir ulang guna mendapat kejelasan agar dapat diterima atas dasar kebenaran universal dan atas apa-apa yang diperjuangkan. Kawan-kawan yang bagaimana? Dan revolusi yang bagaimana? Atas dasar apa revolusi dilaksanakan? Seberapa penting revolusi pada saat itu dan juga pada saat ini untuk orang banyak? 


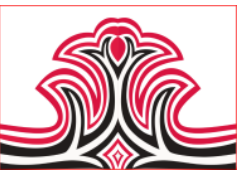

Pertanyaan-pertanyaan di atas bersandarkan pada bentuk lukisan itu sendiri, yakni karakter dalam lukisan tersebut. Sebelum melakukan pembacaan lebih jauh, dapat dipaparkan karakter yang dimaksud, di antaranya seorang seniman berkacamata dengan topi khas, seorang panglima maupun jendral, pemikir dan juga seorang anak-anak, anak muda hingga orangtua. Beberapa tokoh lukisan yang terdapat pada bagian kanan dan terutama pada bagian kiri lukisan, tidak begitu jelas terlihat, kalaupun terlihat hanya saparuh wajah samar. Setiap tokohnya menghadap dengan posisi yang berbeda; anak muda yang berada di bagian tengah atas lukisan menatap bernas kedepan dengan background warna terang dan gelap; merah, kuning, coklat, yang masing-masing warna menandakan amarah, kekecewaan, ketakutan dan memungkinkan penafsiran beragam. Beberapa tokoh lainnya, sebagiannya lagi menyamping - menghadap kearah "kanan". Mengapa tidak satupun tokoh menghadap ke "kiri"? Seakan sekelompok tokoh yang saling menghadap (berpaling) ke kanan memberi kesan kesatupahaman. "Kawan-kawan Revolusi" dalam realitas sejarah.

Lukisan Sudjojono ('Kawan-kawan Revolusi') mengendap di dalamnya suatu persoalan yang dapat kita jumpai saat sekarang ini, bahkan akrab ditengahtengah masyarakat. Lukisan berjudul 'Kawan-kawan Revolusi' dilukis pada tahun 1947, pada bagian lukisan terentang kesedihan seorang anak, memperlihatkan wajah ketakutan dalam pangkuan seorang laki-laki separuh baya. Apakah anak tesebut dapat juga disebut pejuang revolusi atau dampak dari revolusi? Kenapa masih juga terentang tangisan ketika revolusi dijalankan? Pada umumnya tokoh-tokoh dalam lukisan terlihat kaku, masing-masing terkesan memendam kecurigaan antar satu dengan yang lainnya. Perlu disadari, lukisan ini dibuat dua tahun setelah kemerdekaan bangsa Indonesia. Ini merupakan kondisi dimana masyarakat masih dibayang-bayangi rasa anxitas (kecemasan) mendalam atas peristiwa berdarah sebelumnya dan juga tragedi yang akan datang. Bukan tidak mungkin, dua tahun Indonesia merdeka persoalan serupa masih membayang, bahkan persoalan kemerdekaan masih dipertanyakan pada saat sekarang.

Pertanyaannya, bagaimana posisi perempuan dalam perjuangan bangsa Indonesia, sehingga tidak satupun terlihat dalam lukisan tersebut? Apakah mutlak kaum adam yang menjadi andil besar dalam perjuangan Indonesia? Bukankah memasak, mencuci, membuat kopi disela-sela tetes keringat suami adalah cara tersendiri bagi perjuangan kaum perempuan atas
Gorga Jurnal Seni Rupa

Volume 09 Nomor 01 Januari-Juni 2020

p-ISSN: 2301-5942 | e-ISSN: 2580-2380

kehormatannya, anak cucunya dan juga bangsanya? Atas pertanyaan sebelumnya, mengapa Sudjojono memberi judul 'Kawan-kawan Revolusi' pada karyanya? Apakah judul tersebut dipahami sebatas harafiah dalam rangka mengenang jasa pahlawan tanpa tendensi tertentu atau sebaliknya, lukisan ini merupakan kritik yang ditujukan pada pejuang kita?

Umumnya manusia memiliki sifat yang sama hanya cara hidup yang berubah. Materi yang dipersoalkan saja berubah akan tetapi kalangan masyarakat hipokrit (munafik), penindasan, kekerasan, pembunuhan, penzaliman, sifat-sifat ini bukanlah hal baru di tengahtengah masyarakat hari ini. Sehubungan dengan lukisan Sudjojono yang berjudul 'Kawan-kawan Revolusi' banyak hal yang mesti diragukan adanya. Realitas bukanlah kebenaran mutlak, keberadaan kebenaran mesti disangsikan, diragukan, dipertanyakan, sejauh mana kebenaran dapat disebut benar dan terutama dapat diterima oleh akal sehat.

\section{KAJIAN TEORI}

Penelitian ini bersandarkan pada analisis terhadap gambar-gambar tokoh yang terdapat dalam lukisan Sudjojono berjudul "Kawan-kawan Revolusi". Oleh karena itu, kerangka teoritik yang dianggap relevan ialah teori semiotik, khususnya Teori Semiotika Menurut Ferdinand de Sausure.

Teori Semiotik ini dikemukakan oleh Ferdinand De Saussure (1857-1913). Dalam teori ini semiotik dibagi menjadi dua bagian yaitu penanda (signifier) dan pertanda (signified). Penanda dilihat sebagai bentuk/wujud fisik dapat dikenal melalui wujud karya arsitektur, sedangkan pertanda dilihat sebagai makna yang terungkap melalui konsep, fungsi dan/atau nilainlai yang terkandung didalam karya arsitektur. Eksistensi semiotika Saussure adalah relasi antara penanda dan petanda berdasarkan konvensi, biasa disebut dengan signifikasi. Semiotika signifikasi adalah sistem tanda yang mempelajari relasi elemen tanda dalam sebuah sistem berdasarkan aturan atau konvensi tertentu. Kesepakatan sosial diperlukan untuk dapat memaknai tanda tersebut. Menurut Saussure, tanda terdiri dari: Bunyi-bunyian dan gambar, disebut signifier atau penanda, dan konsepkonsep dari bunyi-bunyian dan gambar, disebut signified.

Dalam berkomunikasi, seseorang menggunakan tanda untuk mengirim makna tentang objek dan orang lain akan menginterpretasikan tanda tersebut. Objek bagi Saussure disebut "referent". Hampir serupa dengan Peirce yang mengistilahkan interpretant untuk 


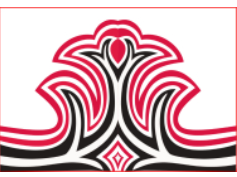

signified dan object untuk signifier, bedanya Saussure memaknai "objek" sebagai referent dan menyebutkannya sebagai unsur tambahan dalam proses penandaan. Contoh: ketika orang menyebut kata "anjing" (signifier) dengan nada mengumpat maka hal tersebut merupakan tanda kesialan (signified). Begitulah, menurut Saussure, "Signifier dan signified merupakan kesatuan, tak dapat dipisahkan, seperti dua sisi dari sehelai kertas." (Sobur, 2004).

Menurut Saussure, tanda mempunyai dua entitas, yaitu signifier (signifiant/ wahana tanda/ penanda/ yang mengutarakan/ simbol) dan signified (signifiel makna/ petanda/ yang diutarakan/ thought of reference). Tanda menurut Saussure adalah kombinasi dari sebuah konsep dan sebuah sound-image yang tidak dapat dipisahkan. Hubungan antara signifier dan signified adalah arbitrary (mana suka). Tidak ada hubungan logis yang pasti diantara keduanya, yang mana membuat teks atau tanda menjadi menarik dan juga problematik pada saat yang bersamaan (Berger, 2010).

\section{METODE PENELITIAN}

Penelitian dilaksanakan dengan metode deskriptif kualitatif. Data dikumpulkan dengan cara studi pustaka. Studi kepustakan ialah segala usaha yang dilakukan oleh peneliti untuk menghimpun informasi yang relevan dengan topik atau masalah yang akan atau sedang diteliti. Informasi itu dapat diperoleh dari buku-buku ilmiah, laporan penelitian, karangankarangan ilmiah, tesis dan disertasi, ensiklopedia dan sumber-sumber tertulis baik tercetak maupun elektronik.

Studi kepustakaan merupakan suatu kegiatan yang tidak dapat dipisahkan dari suatu penelitian. Teoriteori yang mendasari masalah dan bidang yang akan diteliti dapat ditemukan dengan melakukan studi kepustakan. Selain itu peneliti dapat memperoleh informasi tentang penelitian-penelitian sejenis atau yang ada kaitannya dengan penelitiannya. Dengan melakukan studi kepustakan peneliti dapat memanfaatkan semua informasi dan pemikiranpemikiran yang relevan dengan penelitian.

Penelti melakukan studi kepustakaan baik sebelum maupun selama melakukan penelitian. Studi kepustakan memuat sitematis tentang kajian literatur dan hasil penelitian sebelumnya yang ada hubungannya dengan penelitian yang akan dilakukan dan diusahakan menunjukkan kondisi mutakhir dari bidang ilmu tersebut. Adapun perihal yang mendorong
Gorga Jurnal Seni Rupa

Volume 09 Nomor 01 Januari-Juni 2020

p-ISSN: 2301-5942 | e-ISSN: 2580-2380

perlunya dilakukan studi pustaka atau literatur ialah menemukan suatu masalah untuk diteliti, dalam arti bukti-bukti atau pernyataan bahwa masalah yang akan diteliti belum terjawab atau belum terpecahkan secara memuaskan atau belum pernah diteliti orang mengenai tujuan, data dan metode, analisa dan hasil untuk waktu dan tempat yang sama. Mencari informasi yang relevan dengan masalah yang akan diteliti. Mengkaji beberapa teori dasar yang relevan dengan masalah yang akan diteliti, menggali teori-teori yang relevan dengan permasalahan penelitian dan melakukan komparasi-komparasi dan menemukan konsep-konsep yang relevan dengan pokok masalah yang dibahas dalam penelitian.

Ada beberapa macam sumber informasi yang dapat digunakan peneliti sebagai bahan studi kepustakaan diantaranya yaitu;1) Jurnal Penelitian: dalam jurnal ini beberapa hasil penelitian terpilih diterbitkan sehingga dapat digunakan sebagai acuan bagi perkembangan ilmu pengetahuan. 2) Buku: buku merupakan sumber informasi yang sangat penting karena sebagian bidang ilmu yang erat kaitannya dengan penelitian diwujudkan dalam bentuk buku yang ditulis oleh seorang penulis yang berkompeten di bidangnya. 3) Surat Kabar Dan Majalah: media cetak ini merupakan sumber pustaka yang cukup baik dan mudah diperoleh di mana-mana. 4) Internet: Kemajuan teknologi membawa dampak yang sangat signifikan di bidang informasi, peneliti dapat langsung mengakses intrernet dan mendapatkan informasi yang diinginkan dari berbagai negara dengan sangat cepat.

\section{HASIL DAN PEMBAHASAN \\ 1.Hasil}

Lahirnya berbagai pandangan hidup di antara pemimpin bangsa ini semakin mempertegas kesimpangsiuran masa depan bangsa akan mau dibawa kemana, di mana akan dilabuhkan; sosialisme, nasionalisme, komunisme, liberalisme, kapitalisme dan masih banyak lagi. Semakin tegas pergesekan ideologi yang lahir semakin jelas pula bagaimana penderitaan rakyat bangsa ini. Penderitaan dari jajahan fisik yang berdampak pada kejiwaan atau pun mental. Sehingga dampak lain dari itu, suatu sikap berkesian pun akan lahir dari upaya mendengarkan, menurut suatu grup moraliserende-mensen (orang-orang yang sok bermoral) atau menjadi budak dari partai ini atau partai itu. Seniman harus merdeka-semerdekanya, terlepas dari segala ikatan moral maupun tradisi untuk bisa hidup subur, segar, dan merdeka (Sudjojono: 2012).

Ketertindasan yang dialami bangsa Indonesia menurut 
Sudjojono berdampak pada sikap atau mental yang kurang menguntungkan lajunya perkembangan bangsa Indonesia. Di balik itu, bagi Sudjojono dan kawankawan, ketertindasan juga merupakan cambuk untuk bangkit menantang invansi, mempertahankan prinsip hidup dan ideologi, terutama harga diri. Dalam karyanya, di tengah-tengah maraknya ideologi yang mengambang di tanah air (bangsa Indonesia), gagasan-gagasan estetika Sudjojono lebih menekankan dan menyerukan pentingnya Nasionalisme, meskipun pengungkapannya Internasional (Universal). Pengungkapan nilai-nilai estetis tidaklah dapat berdusta, seutuhnya jujur, karena kejujuranlah nilai-nilai itu menjadi bermakna. Kejujuran kalbu dalam mengamati lingkungan, baik lingkungan sosial maupun budaya akan menumbuhkan jiwa kritis terhadap segala sesuatu. Itulah yang kemudian menjadi semangat Nasionalisme. Melalui pengungkapan yang jujur, seorang seniman akan mengungkapkan realitas yang sebenarnya, baik kejelekannya atau kebaikannya.

Ketertindasan menjadikan sebagian rakyat Indonesia (seniman) kehilangan pandangan hidup, dan hanya mampu melihat kulit luar tapi samar dalam melihat kedalaman. Sehingga pengungkapan ke dalam karya pun sebagian seniman pada masanya cenderung mempresentasikan sesuatu hal yang indah-indah, yaitu tidak lain dari lukisan-lukisan pemandangan: sawah dibajak, sawah yang berair jernih dan tenang atau gubuk di tengah-tengah padang padi, tidak lupa pula pohon-pohon kelapa di dekatnya atau bambu dan gunung yang kebiru-biruan di jauh mata (Sudjojono: 2006). Tidak mampu menjangkau penderitaan sebagian jiwanya dari apa yang mereka lihat. Berbalik dengan Sudjojono, yang lebih menekankan prinsip hidup, mampu menjangkau sebagian jiwanya yang tercerabut. Sehingga bagi "Kawan-kawan Revolusi" untuk dapat sedikit menunda rasa besar hati, dan seyogianya mencoba mengamati dan memahami jika dalam gaya ungkap Sudjojono terdapat kejujuran yang benar-benar pahit. Pahit, itulah realitas yang sebenarbenarnya realitas pada masanya. Berindah-indah baginya menandakan sikap yang hipokrit (munafik), bertolak belakang dari realitas, tidak memiliki nilai, dan tidak lebih hanya sekedar mengisi waktu luang dengan tujuan gaya-gayaan (nyeniman). Senada dengan itu, Jakob Sumardjo menegaskan dasar ideologi seni modern Indonesia (pada umumnya) dengan bentuk ungkapan; "perkembangan seni modern Indonesia tidak di waktu ada kemewahan, tetapi malahan di waktu kita serba kekurangan, mengalami perjuangan, bencana dan penderitaan" (Sudjojono: 2006).
Pahit memang, namun begitulah adanya Sudjojono, sebagian koleganya menyatakan gaya ungkapnya yang lugas, tepat mengena sasaran, meski terkadang ada juga kesamaran. Hal tersebut menandakan begitu sesaknya pahit realitas yang dirasakannya, sehingga dalam pengungkapannya terkesan acak, sesak, seperti dalam lukisannya yang berjudul 'Kawan-kawan Revolusi'. Karena pada dasarnya seorang seniman yang mampu dengan benar-benar jujur mengekspresikan dirinya sendiri pada hakikatnya dapat dilihat dari hubungan realitas dan karya seninya yang merupakan hakikat dirinya, yang oleh Sudjojono disebut sebagai jiwa ketok (“jiwa yang tampak"). Terlepas apapun objeknya, jika seorang seniman berpegang pada prinsip diri, akan terlihat jiwa yang besar.

Jiwa besar yang terdapat dalam lukisan menandakan pandangan estetika yang "membumi". Estetika dalam karya menandakan adanya hubungan antara karya seni dan penikmatnya (realitas yang diungkapkan). Dalam paham estetika, estetika seyogianya mewakili suatu paham, pandangan hidup yang mewakili orang banyak menuju keselamatan hidup, tentram dan sejahtera. Jika hal tersebut telah dilaksanakan, akan dapat dilihat bagaimana estetika dalam karya seni "ini" maupun "itu". Masing-masing akan memiliki ciri, karena berpijak dari suatu pandangan hidup.

\section{Pembahasan}

Kembali pada pandangan Sudjojono, seperti adagiumnya; 'seni adalah jiwa ketok (tampak)'. Selintas, lukisan ini menunjukan bagaimana keadaan jiwa Sudjojono tampak, mewujud sebagai bentuk kondisi jiwa yang kemungkinan anggapan; mengingkari atau mengkritisi dengan menelaah sesuatu yang tersirat dari yang tersurat. Meskipun begitu, belum pula dapat disimpulkan bagaimana pandangan atau penilaiannya terhadap perempuan pada masa revolusi. Sekiranya terlalu dini penilaian disimpulkan jika hanya meninjau dari sudut pandang feminis.

Menilik sejarah perjuangan kemerdekaan Indonesia, dapat dikatakan bahwasanya kemerdekaan tidak hanya di bawah pengaruh kaum laki-laki. Lukisan Sudjojono bertolak belakang dengan sejarah yang menyatakan dengan sikap teguh gagah berani bahwasanya perempuan pada suatu ketika dapat juga menjadi tameng terutama dari segi bagaimana menjaga harkat dan martabat sesuai dengan kodrat mereka sebagai perempaun yang juga harkat dan martabat dari suatu bangsa. Apakah rentetan sejarah di atas masih memungkinkan untuk dinafikan? Pertanyaan ini bukan 
berarti Sudjojono sudah menafikan kaum perempuan, melainkan mencoba membeturkan realitas-realitas dengan pola pikir Sudjojono dalam memperjuangkan kebudayaan Indonesia khususnya dalam bidang seni rupa, untuk dapat dikerucutkan menuju kesimpulan yang kualitatif.

Banyak celah untuk dijadikan bahan pertimbangan, dalam memilah-milah dan menimbang-nimbang halhal yang barangkali terlupakan - bahkan - oleh seniman sendiri yang penciptaan karya mereka pada umumnya berpijak pada falsafah kemanusiaan, nilainilai moral, etika, estetika, religi, intelektual dan banyak hal lainnya. Dan jika semata-mata, tanpa mengikut campurkan ruang interpretasi yang merujuk pada sosio histori; dimana letak 'etika' Sudjojono sebagai individu atau seniman yang nota bene menjunjunag harkat dan martabat orang banyak ketika tidak mengikutsertakan kaum perempuan dalam 'kawanan revolusi'-nya. Secara kesejarahan, lukisan Sudjojono begitu timpang. Dan jika tidak ingin dikatakan bahwasanya terdapat ketimpangan sejarah dan nilai-nilai yang paradoks, tentu lukisan tersebut menyajikan sesuatu yang tersirat. Entah atas dari semua ini, Sudjojono mencoba (secara tidak langsung) mendidik/mengajarkan dalam langkah awal pergerakan seni rupa di Indonesia di bawah naungan PERSAGI bagaimana apresiator tidak menelan mentah-mentah apa yang ditawarkan. Dalam menikmati, menginterpretasi dan menilai karya seni, apresiator perlu memamah dan berganti-ganti sudut pandang dalam melihat makna yang terkandung dalam suatu bentuk hasil 'ciptaan' (karya seni).

Tidak sebatas memajukan perkembangan seni rupa itu sendiri. Usaha pengembangan perlu pula dilakukan dalam bagaimana suatu karya seni rupa diapresiasi, dapat dinikmati oleh masyarakat banyak - karena di saat terwujudnya gagasan di atas kanvas, seketika itu pula seorang seniman kehilangan 'kesenimanannya'. Seperti yang sudah disinggung sebelumnya, keterkaitan antara lingkungan (sumber ide atau gagasan), seniman, karya seni dan penonton saling memperngaruhi satu sama lain. Keempat unsur ini merupakan 'sistem produksi tanda' tanpa batas, yang masing-masing memiliki ruang privasi tersendiri, hukum tersendiri. Lingkungan adalah rangsangan atas terciptanya suatu karya seni di tangan seniman, dan kemudian penonton kembali pula memproduksi imajiimaji (tanda-tanda) yang distimulus oleh karya yang sedang ditonton. Sehingga buah pikiran yang diungkapkan lewat bahasa yang dituturkan, juga memungkinkan kembali menjadi sumber ide dan gagasan. Ide atau gagasan tersebut cukup besar kemungkinan memancing kemungkinan-kemungkinan ide lainnya yang terkadang dapat membatalkan atau lebih membangun ide sebelumnya dalam sitem penciptaan karya seni.

Untuk itu, sekiranya upaya yang dilakukan Sudjojono dengan - bahwasanya masyarakat apresiator dalam era masa kermerdekaan Indonesia di mana dua tahun setelah mewujud karyanya berjudul 'Kawan-kawan Revolusi', penonton perlu dididik guna menstabilkan dinamika perkembangan seni rupa pada wilayah seniman, kritikus (yang pada umumnya penyebrangan pikiran oleh) dan penonton. Mendidik dimaksud, dengan tidak sebatas menyajikan suatu karya seni tanpa tendensi apapun yang disebut sebagai aliran seni popular. Melainkan karya seni juga dapat mengajarkan apresiator mempelajari kesejarahan dengan menampilkan hal-hal yang tidak biasa guna memancing daya kritis pambacanya (apresiator) kepada hal-hal yang seharusnya.

\section{KESIMPULA DAN SARAN}

\section{Kesimpulan}

Berangkat dari paparan pada halaman-halaman sebelumnya, sangat jelas bahwasanya dalam 'Kawankawan Revolusi' tersirat kritikan, kecaman, kekecewaan mendalam dari Sudjojono sendiri atas segala keganjilan hidup yang dirasakan semasa hidup atau pun dalam kehidupan yang akan datang. Maknamakna yang lahir secara spontan tidak henti-hentinya bermunculan dari dalam kanvas. Bayangan-bayangan kepedihan dan penderitaan dari masa lalu ataupun masa yang akan datang.

Lahir dan besar di tengah-tengah masyarakat yang setiap waktu selalu merasa cemas; seperti apa hidup yang mesti dijalani esok hari? Membuat Sudjojono sangat peka dalam pelukisan-pelukisan apa-apa yang tersirat dalam realitas, sehingga hasil dari setiap goresan pada kanvas dapat pula menjadi saksi kejamnya peradaban antar manusia di tanah bangsa (Indonesia) ini. Inilah fokus utama kenapa 'Kawankawan Revolusi' hadir. Jiwa nasionalis yang begitu tinggi pun tergambar dalam 'Kawan-kawan Revolusi' Mungkinkah 'Kawan-kawan Revolusi' menandakan ketakjuban dan suatu bentuk sanjungan Sudjojono terhadap pahlwan-pahlawan bangsa, mengingat kenyataan pahit yang telah diterima rakyat kita? Jika benar adanya, dapat pula kita kritisi; bukankah begitu banyak deretan nama-nama revolusioner dari kaum perempuan yang sama-sama memikul beban perjuangan seperti halnya kaum laki-laki. 


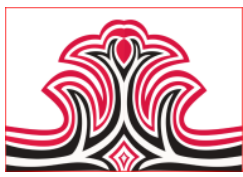

2.Saran

Pembacaan atas tanda-tanda sepertinya tidak dapat ditemui ujungnya, terutama dalam hal karya seni. Karya seni selalu saja memiliki daya tarik - terutama karena sesuatu yang tersirat di dalamnya. Sesuatu itupun tidaklah berbatas, cukup luas sejalan dengan sudut pandang pembaca yang memaknainya. Dalam hal ini, sudut pandang pembaca memiliki peran dalam membangun makna, kebaruan perspektif, suatu alternatif gagasan dalam memaknai karya seni. Oleh karena itu pula, karya seni pun kaya akan makna. Atas dasar itu, seyogianya dilakukan pemaknaan dari perspektif yang berbeda agar karya seni dapat dimaknai dari masa dan kondisi zaman yang berbeda.

\section{DAFTAR RUJUKAN}

Berger, Arthur Asa. (2010). Pengantar Semiotika: Tanda-tanda Kebudayaan Kontemporer. Yogyakarta: Tiara Wacana.

Sobur, Alex. (2004). Analisis Teks Media. Bandung: Remaja Rosdakarya.

Sp, Soedarso. (2000). Sejarah Perkembangan Seni Rupa Modern. Jakarta: Studio Delapan Puluh.

Sudjojono, S. (2006). Seni Lukis Indonesia Sekarang dan yang Akan Datang, dalam Seni Rupa Modern Indonesia; Esai-Esai Pilihan. Jakarta: Grafika Mardi Yuana.

(2012). Kesenian Melukis di Indonesia; Sekarang dan yang Akan Datang, dalam Seni Rupa Indonesia dalam Kritik dan Esai, Jakarta: Semarak TataWarna. 